\section{Rainfall in Southern Italy and Tripoli.}

PROF. FILIPPO EREDIA, of the Italian Meteorological Service, has recently contributed some further climatological studies to the many which he has already published. One of these (Nuovi Annali del Ministero per 1' Agricoltura) deals with the seasonal conditions of rainfall in the province of Apulia and the relation of the quantity of precipitation to the number of days of incidence. The matter is important in connexion with the somewhat precarious water supply in that southern Italian province, which during the summer months is affected by the Saharan regimen of drought.

In another publication, on the rainfall of Tripoli (" L'Agricoltura Coloniale," Anno xv., No. 8, I92I), Prof. Eredia shows that there is no foundation for the supposition that the rainfall of the region is steadily diminishing because the country shows signs of progressive desiccation. One might remark that progressive desiccation is considered to be the fact in many parts of Africa other than Tripoli, and that it has been explained by Schwarz and others as due, not to diminishing rainfall, but to a continental configuration which is slowly inducing baneful hydrological changes.

Two other papers on the climates of Gharian and Cussabat on the interior plateau of Tripoli (Bollettino di Informazioni, Nos. 3-4, 7-8, I921) give an interesting glimpse of general climatic conditions based on a few years' records for meteorological observations since the Italian occupation. The mean annual temperature at Gharian, high up on the plateau and more than 2000 feet above sea-level, is about $65^{\circ} \mathrm{F}$., ranging between $83^{\circ}$ in July and $48^{\circ}$ in January, and the mean daily range varies from $30^{\circ} \mathrm{F}$. at midsummer to less than half that value at midwinter. The absolute extremes of temperature recorded at this station were $\mathrm{I} 2 \mathrm{I} \cdot \mathrm{I}^{\circ} \mathrm{F}$. in June and $32 \cdot \mathrm{I}^{\circ} \mathrm{F}$. in December, whilst extreme fluctuations of relative humidity characterise this dry region. The general rainfall of Tripoli is less than 20 inches a year, chiefly confined to winter. In this region we have another instance of the fact that occasional snowfalls at sea-level make a much closer approach to the tropics than is commonly supposed.

\section{University and Educational Intelligence.}

BANGOR.-Prof. D. Thoday of the University of Cape Town has been appointed to the chair of botany, in succession to Prof. R. W. Phillips, who retires after thirty-eight years' service.

Birmingham.-At the Degree Congregation held on July $I$, in the great hall of the University at Edgbaston, the number of degrees conferred was the largest hitherto recorded for the University. Many of the new graduates are ex-service men, and the Principal (Mr. C. Grant Robertson) paid a tribute to the work of these men and their valuable help in creating afresh traditions of the University after the war: "They have given us invaluable service in that necessary work. They brought to the University a breadth and a variety of experience, a maturity of judgment, and an energy and enthusiasm which those who know the University from the inside recognise has been invaluable, and which will leave a permanent imprint on our University life and a permanent addition to our University traditions." The institution by the Government of grants to exservice men was a unique educational experiment and, judging by the experience of Birmingham University, it had proved an unqualified success.

The following degrees were conferred: Doctor of
Science: Mr. R. H. Whitehouse ; Doctor of Medicine Mr. O. J. Kauffmann, Mr. J. Robertson, and Mr. J. W. Russell ; Philosophice Doctor: Mr. F. Adcock, Mr. C. B. Childs, Mr. V. A. Collins, Mr. E. A. F. Reeve, Mr. J. D. M. Smith, Mr. R. E. Stradling, Mr. E. H. Wells; Master of Surgery: Mr. L. P. Gamgee. For the degree of Master of Science, 45 candidates were presented; for the degree of B.Sc. with Honours, there were 74 candidates, and for the ordinary B.Sc. degree, I 57 .

The Vice-Chancellor, Sir Gilbert Barling, announced that a war memorial was to be erected on the east wall of the entrance hall, in the form of three marble panels bearing the names of the members of the University of all ranks who fell in the war. It is expected that the memorial will be unveiled in October next.

Mr. C. G. Payton has been appointed demonstrator in anatomy.

The Ingleby Lecturer for 1924 will be $\mathrm{Mr}$ A. W. Nuthall.

CAMBRIDGE.--In connexion with the meeting of the Royal Agricultural Society (the " Royal Show "), honorary degrees are being conferred on H.R.H. The Duke of York, the Honourable W. H. Taft, Mr. C. R. W. Adeane, Sir G. Greenall, Sir Daniel Hall, Mr. E. S. Beaven, Mr. A. E. Humphries, Mr. E. Mathews, and Mr. G. P. Hawkins. Mr. L. C. G. Clarke, Trinity College, has been appointed curator of the Museum of Archæology and of Ethnology.

LoNDON.-Prof. H. S. Birkett (Dean of the Faculty of Medicine, McGill University) will deliver the Semon Lecture at the Royal Society of Medicine, I Wimpole Street, W.I, on Wednesday, July I2, at 5 o'clock. The subject will be "The development of TransAtlantic Rhino-laryngology." Admission will be free and no tickets will be required.

OXFord.-At the Encaenia, held on June 28, the honorary degree of D.Sc. was conferred on Prof. J. Perrin of Paris and Prof. F. Gowland Hopkins of Cambridge. In introducing Prof. Perrin, the Public Orator (Dr. Godley) referred particularly to his experimental researches in the character and constitution of the atom, and to his determination of the velocity of the component electrons. His scientific investigations had been used in the service of his country, and had contributed largely to its victory in the war. Of the work in biochemistry of Prof. Gowland Hopkins, the Orator found it difficult to speak "in hac patrii sermonis egestate." $\mathrm{He}$ was able, however, to pay tribute in general terms to Prof. Hopkins's abstruse researches into the nutrition and metabolism of living bodies. His discovery of the importance of vitamins was not only of high scientific value, but had also a practical bearing of the greatest interest in the study of disease. Prof: Perrin was greeted by the Vice-Chancellor (Dr. L. R. Farnell, Rector of Exeter College) as " Vir doctissime ; maxime physicae scientiae auctor" ; and Prof. Hopkins as "Vir eruditissime; chemiae explorator insignis ; Universitatis Cantabrigiensis decus."

SHEFFIELD.- Honorary degrees have been conferred on Sir Charles Parsons for his work on the turbine engine, and on Mr. T. W. Hall for researches in palæography and archæology.

Dr. R. H. Chittenden, the well-known authority on dietetics, is retiring from the post of director of the Sheffield Scientific School, Yale University, which he has held since 1898 . He is to be succeeded by Dr. C. H. Warren, now professor of mineralogy at the Massachusetts Institute of Technology and a former assistant at the Sheffield Scientific School, of which he is himself a graduate. 